\title{
The Role Of Counseling Guidance Teachers In Handling Students With Introverted Personality At Tunas Kelapa Samarinda Middle School
}

\author{
Dewi Hendraningrat ${ }^{1 *}$, Pujiyanti Fauziah ${ }^{2}$ \\ ${ }^{1,2)}$ Non Formal Education, Pascasarjana, Universitas Negeri Yogyakarta, Indonesia \\ *dewihendraningrat@gmail.com
}

\begin{abstract}
This study aims to find out (1) What is the personality of introverted students in class IX-B Tunas Kelapa Junior High School Samarinda. (2) The role of the counseling guidance teacher in dealing with introverted students at Tunas Kelapa Samarinda Middle School. This type of research is descriptive qualitative. Data collection in this study was observation, interviews, and documentation. The results of this study indicate that there are students who show introverted personality (1) These students have 6 characteristic attitudes including behaviors that tend to be formal, reserved, inhospitable, less skilled in expressing emotions, easily giving in to circumstances, and easily lagging in following circumstances. (2) The role of the Guidance Counseling teacher is to act as a counselor, consultant, change agent, main preventive agent, and the last role of the Guidance Counseling teacher as a supervisor.
\end{abstract}

Keywords: role of counseling guidance teacher, introvert personality

\section{Introduction}

Humans are perfect beings where every human has a language of communication to convey feelings and whatever he thinks, therefore every human must be able to communicate well and precisely, because the ability to communicate is important to achieve the success of human life. In schools failure in student learning is often caused by a lack of communication skills[1]. Communication is part of social interaction is the relationship between one individual with another individual and can influence each other so that mutual relations can occur. Individuals are born to always connect and communicate with others [2]. Humans as individuals are socially inherent. This means that humans will always and always be in contact with others.

Basically, the personality that is formed in the individual is first obtained from the family environment, because the family is the first source of information for individuals before receiving outside influence. In this family environment the first time individuals get education, guidance, care, habituation and training.

According Yusuf [3], to based on the attitude of his soul, humans can be classified into 2 types of personality, namely extroverted personality and introverted personality. The inequality is a characteristic of every individual that is shown in everyday life, namely in the way of decision making, attitudes and social interactions. Schools that should be a place for students to actualize themselves, a place to develop their potential, a place to socialize apparently not many students are able to do this, there are still many students who seem closed, less able to get along, embarrassed to express their opinions. In this case there must be someone who is able to reduce introverted behavior. Reducing introverted behavior means that 
someone will have the ability to recognize, deal with a variety of people's characters, respond to various social situations and be able to socialize with many people, not just focus on themselves.

In such problems, counseling guidance teachers can overcome them with individual counseling. According to the counselling referred to is as a special service in direct face-toface relations between counsellor and counselee [4]. Individual counseling is a learning process through a special personal relationship between counselor and a counselee is usually done by interview. Through this process it is hoped that students will be more open about the problems that befall him. So that there is no gap between counselor and counselee and to facilitate counselors in understanding problems and providing solutions. The most important thing is encouragement for students to undergo social interaction and provide space for students to explore themselves.

\section{Literature Study and Method}

\subsection{Personality}

Personality can be interpreted as a person's identity, so much to do with the issue of character, nature, which is reflected clearly in one's actions and actions. A person who is personal is aware of himself and can understand precisely his personality. A person with a strong personality is someone who can determine himself, do what, as what, what he wants and so on. Personality generally refers to how each individual appears and impresses other individuals. Basically personality generally only evaluates observable behaviors and personality can change depending on the surrounding situation, basically personality cannot be judged "good" or "bad" because it is neutral. Personality is a certain pattern of traits and characteristics, which is relatively permanent and gives both consistency and individuality to one's behavior. J.Feist \& Gregory J.Feist explains that specifically personality includes all relatively permanent traits or characteristics that cause consistent human behaviour [6].

Human personality is based on its purpose in life which is influenced by the past and future of humans. In psychoanalytic theory there are two aspects of personality, attitude and function. Attitudes consist of introverts and extroverts, while the functions of thingking, feeling, sensing and intuiting.

\subsection{Personality Development}

Freud was the first theoretician to focus on the development of personality, and stressed the importance of the role of infancy and early childhood in shaping one's character. Human development in psycho-analytic is a very thorough picture of the process of psychosocial and psycho-sexual development, from birth to adulthood [7]. Opinions childhood as a crucial period in one's development. The canalisations that occurred in childhood remained influential for the following periods. Indeed, more canalization can be "replaced" by canalization which occurs in the following periods, but it is not lost. In certain conditions, such as frustration, conflict, canalization anxiety that may appear again in its original form.

Personality develops in response to four main sources of stress, namely the process of physiological growth, frustration, conflicts, and threats. As a direct result of the increased tension caused by these sources, the individual is forced to learn new ways to reduce stress. This learning process is meant by personality development.

\subsection{Personality Characteristics}

Adjustment can be interpreted as an individual response, both behavioral and mental in an effort to overcome the needs from within, emotional tension, frustration and conflict and 
maintain harmony between the fulfillment of these needs with the demands (norms) of the environment [8]. Suggested that the characteristics of a healthy adjustment or a healthy personality are characterized [9] by: (a) Being able to assess themselves realistically means being able to assess their strengths and weaknesses as they are, (b) Being able to appraise situations realistically means being able to deal with situations that are experienced realistically and are willing to accept them fairly, and are not perfectionist. (c) Being able to assess the achievements obtained realistically, the achievements obtained by someone is not arrogant, whereas if it fails do not experience excessive frustration but instead can be hopeful. (d) Accept responsibility, have confidence and have the spirit to be able to carry out tasks and resolve problems properly. (e) Independence. (f) Can control emotions. (g) Goal oriented. (h) Outgoing oriented. (i) Social acceptance. (j) Have a philosophy of life. (k) Happiness.

\subsection{Introverts}

Introverts are a type of personality type that are owned by people who tend to focus on something that is within themselves. Introverts tend to focus on what is in their own hearts and minds. Unlike extroverts who tend to be active in socializing with friends and people they know. Introverts are more often busy and active in their own thoughts. Introverts have a very active mind, not infrequently they often argue and communicate with their own thoughts. Not that they are crazy, but their thinking power is very broad, full of ideas and imagination. So they like having other souls in themselves, so they tend to prefer to argue and communicate with their own thoughts than socializing with people.

People who have introverted personalities show a tendency to develop symptoms of fear and depression, characterized by tendencies of obsession, apathy, unstable autonomic nerves besides their relatively high intelligence, vocabulary of many, and tend to firm to the establishment. Introverted as a person who shows personality with the characteristics of intraversion characteristics, those who tend to withdraw from social contact, their interest is more directed to the mind and into their own experiences [10].

Introverted personality is an orientation into oneself. In short, an introvert is someone who tends to withdraw from social contact. His interests and attention are more focused on his own thoughts and experiences. An introvert tends to feel capable in an effort to provide for himself, whereas extroverts need other people.

Introversion is the flow of psychic energy in a direction that has a subjective orientation. Introverts have a good understanding of the world within themselves, fantasies, dreams, and perceptions that are individual [6]. These people will accept the outside world very selectively and with their subjective views. Jung said introverted behavior as a quiet person, keep away from external events, do not want to get involved with the objective world, do not like being in a crowd, feel lonely and lose in a crowd. He does things according to his own way, closing himself to the influence of the outside world. He is not easy to believe, sometimes suffer from feelings of inferiority, because of that he is easily jealous and jealous. He confronts the outside world with a system of self-defence that is systematic and thorough, appearing to be a scientist, careful, cautious, obedient, polite, and suspicious.

The introvert is a self-oriented person, in the sense that he is a loner, less concerned with the outside world. Generally introverts like to be introspective and busy with their own internal lives. Of course they also observe the outside world, but they do so selectively, and use their own subjective views [11]. 


\subsection{Characteristics of Introverts}

Introverts are those who are skilled in traveling to the "inner world," themselves. They always try to understand themselves by doing a lot of reflection. Eventually, they become aware of what is their purpose in life. In his personal research introverts are the innate nature of a closed person who prefers to stimulate or dialogue with himself. Personal introverts can be seen from his habits since childhood, if other children are more active, happy to move, happy to tell all their activities, introverted children prefer to be alone in a closed room or room. But introverts are not entirely happy to be alone, it's just that they prefer to have a few close friends they can trust to tell about personal things about themselves. This concept emerged from a psychologist, and is now an important variable in various personality tests. By classifying introverts as minorities, even though minorities the role of introverts in social life is very prominent.

Introverted personality traits are as follows: (a) It's easier to write than to speak.(b) Often filled with anxiety. (c) Embarrassed and offended. (d) Tend to be radical. $€$ Loves to read books and magazines. (f) More influenced by subjective feelings. (g) Somewhat closed soul. (h) Liked working alone. (i) Be very careful of suffering and take care of what belongs to him. (j) Difficult to adjust and rigid in the association [12].

Developed Jung's theory states that there are complex characteristics with an introverted personality type, including: (a) His attention was fixed on the world from within him. (b) Getting energy from within himself. (c) Filtering ideas and thoughts from within. (d) Tends to communicate through writing. (e) Think first before talking. (f) Having difficulty in establishing relationships with others. (g) Has a closed nature. (h) Difficult to adapt to the new environment. (i) Prefer to work alone. [13].

According to him the characteristics of introverted personality types can be shown through: (a) Attitudes and behaviors tend to be formal. (b) Quiet. (c) Not friendly. (d) Less skilled at expressing emotions and not excessive. (e) Tends to give up easily. (f) Left behind in following circumstances [14].

Based on some of the opinions above it can be concluded that the type of introvert has the characteristics tend to be more shy, and have a fixation on the things that happen in them and always try to be introspective, lagging in following the circumstances, seeming quiet, not friendly, prefers to be alone, and experience obstacles to the quality of the behavior displayed.

An introvert is often preoccupied with himself and less sensitive to his environment. In the end the environment also cannot accept an introvert well. They know what they want, but it is difficult to communicate it to others. This makes introverts often labeled as weirdos. To understand the thoughts of an introvert, you must spend more time communicating with him. This is why when we talk to an introvert, we will be invited to a deeper conversation.

\subsection{The Role of Teacher Guidance and Counseling}

The role of counselor or guidance and counseling teacher [15] includes:

a. As A Counselor. The meaning of counselee as a service for anyone who seeks help from someone who is professionally trained (counselor), in the services provided can be individually or in groups by directing the counselee to understand and deal with real-life situations so that they can make decisions based on that understanding to the happiness of his life.

b. As A Consultant. An effective counselor will build to have a cooperative relationship with various parties in the interest of the counselee, so that the role is not only limited to the counselor as a counselor but the role of the counselor as a consultant becomes a demand that must be fulfilled. 
c. As An Agent Of Change. The overall environment of the counselee must be able to function so that it can affect mental health for the better and the counselor can use that environment to strengthen and enhance the function of the counselee.

d. As a Primary Deterrence Agent. As an agent to prevent wrong development and / or repeat difficulties. The emphasis is mainly on providing educational strategies and training as a way to acquire or improve interpersonal skills.

e. As A Manager Or Coach. Counselors must be able to handle various aspects of service programs that have variety, variety, expectations and roles such as program planning, goal setting, financing and decision making.

\section{Results and Discussion}

\subsection{Results}

3.1.1 Students with Introverted Personality

a. Attitudes and behaviors tend to be formal

Based on the results of interviews about indicators of attitudes and behaviors tend to be formal with sub-indicators of regular lifestyle and behaviors tend to be passive that has been done to 4 respondents by researchers. In these interviews MM students always arrive on time to school and always obey school rules. Counseling Guidance Teachers and homeroom teachers also said that MM students were less active in participating in school activities but in academic matters MM was a smart student. MM's friends say that MM is always fully dressed but sometimes MM's clothes or hijab often look untidy or not ironed.

b. Quiet

Based on the results of interviews about the quiet indicator with the sub-indicators like being alone, keep a distance, and not say much that was done to 4 respondents by researchers. MM's friends say that MM doesn't like mingling. prefers to be alone, even if there's a problem MM never tells anyone. In class, only has one close friend. Even the homeroom teacher said that if MM left the classroom, MM was often seen alone or only accompanied by one of his closest friends. MM also rarely seen interacting with peers.

c. Not friendly

Based on the results of interviews about indicators not friendly with sub-indicators of closing themselves and easily offended that has been done to 4 respondents by researchers. MM said that he often refused when his friends asked him to go for a walk after school and MM often felt offended when a friend made fun of him, but MM just kept quiet and remained silent. MM is very sensitive in responding to something and often gets angry just because of something trivial. MM also rarely greets others first. Even if they say hello, MM only greets one close friend.

d. Less Skilled in Expressing Emotions and Not Excessive

Based on the results of interviews about indicators less skilled in expressing emotions and not excessive with sub-indicators more fluently writing than speaking and shy that has been done to 4 respondents by researchers. MM students don't talk much, prefer writing and are not confident or shy which is marked by MM's difficulty in mingling with their peers.

e. Tend To Easily Give Up Circumstances

Based on the results of interviews about indicators tend to easily give up on the situation with pessimistic sub-indicators and often complain that has been done to 4 respondents by researchers. The BK teacher said that MM students appear to lack confidence especially because they lack physical support. MM also sometimes often complains to close friends about him. That's what makes MM students feel inferior and not confident in their friends. 
f. Left Behind Following the Circumstances

Based on the results of interviews about indicators lagging in following the situation with sub-indicators interested in their own thoughts and feelings, withdrawing from the environment, and like working alone that has been done to 4 respondents by researchers. MM students say that they prefer to do their own tasks than in groups. Therefore, MM students are very difficult when there are teachers who give group work assignments. When working on group assignments, MM students often feel inferior because their friends do not accept the situation even though MM students are students who are smart enough in their class. MM students, including those who do not easily trust others, therefore MM rarely ask for advice or opinions with others and more often make their own decisions.

3.1.2 The Role of Counseling Teacher Guidance

a. Guidance and Counseling Teacher As Counselor

Dyah as a guidance and counseling teacher, said that one of them is by promoting Guidance and Counseling services to students by promoting the Guidance and Counseling programs and services that will be implemented. And the services used to handle introverted students are individual counseling services with the aim that introverted students are more open and these students can interact well.

b. Guidance and Counseling Teacher As Consultant

Dyah as a guidance and counseling teacher said that the Guidance and Counseling teacher collected data about introverted students from reports from the homeroom teacher and student's peers.

c. Guidance and Counseling Teachers As Agents of Change

Dyah as a guidance and counseling teacher said that after the individual counseling service, there was a change from the introverted student. Where the student who previously was very difficult to interact now becomes more active. Both introverts or students who are not also given an understanding of the positive things that exist in themselves and give them advice and motivation so that they are mentally and physically healthy so that they can think more positively about themselves without having to shut down so that they can better interact with friends -her friend.

d. Guidance and Counseling Teachers As Primary Prevention Agents

Dyah as a guidance and counseling teacher said that to prevent introverted students from developing into negative directions is to convey messages through classical guidance or individual counseling services about things that support them in a positive direction, whether they are channel it to hobbies or things they like. The aim is to prevent them from developing in a negative or undesirable direction.

f. Teacher guidance and counseling as a guide

Dyah as a guidance and counseling teacher said next.

\subsection{Discussion}

From the description of the theory above, it can be seen that introverted personality has several characters according to experts, but in this study, there were found only a few introverted personality traits in MM students including: tend to be formal, reserved, not friendly, less skilled in expressing emotions and not excessive, tend to give up easily to circumstances, and lag behind in following circumstances. The results obtained are in accordance with the wishes of researchers who only examine students with introverted personalities. 
The role of counselor or guidance and counseling teacher according to him Feist Jess \& Gregory[15] among others, is as a counselor, consultant, change agent, main preventive agent, and the last role of the Guidance and Counseling teacher as a supervisor. In this study, all the roles of the guidance and counseling teacher at Tunas Kelapa Samarinda Middle School were due to the fact that there were guidance and counseling services at the school. And the role of the guidance and counseling teacher is also very good, because they handle MM students who have introverted personalities with patience and seriousness, and maintain all the privacy matters that he tells. This is also reinforced by research conducted by Indah Puji Lestari with the title "The Role of Counseling Guidance Teachers in Helping Introverted Students". The conclusion of this study is that the role of the counselor to help guide and direct students to be able to tell the problem and not to bury their own problems has been carried out properly. In addition to carrying out classical guidance in the class of guidance and counseling teachers also receive reports or notes from homeroom teachers and closest friends of introverted students, so that guidance and counseling teachers can provide alternative assistance to introverted students.

\section{Conclusion}

Based on the results of research and discussion conducted by researchers regarding introverted students in class IX-B at Tunas Kelapa Samarinda Junior High School, it can be concluded that students who have introverted personality have attitudes tend to be formal, quiet, unfriendly, less skilled in expressing emotions and not excessive, tend to easily give in to circumstances, and lag behind in following circumstances.

Introverted students also not care about appearance and are always alone which makes introverted students shunned by their peers. Lack of understanding of individual self so that they cannot recognize themselves. In addition students have introverts very difficult to mingle or interact with others. This is very influential on the formation of the introvert student's personality.

The role of guidance and counseling teachers in handling introverted students is to socialize and provide counseling services, one of which is by conducting individual counseling, collecting data and information from homeroom teachers and peers about introverted students, seeing the changes that occur in students after being given counseling. , preventing introverted students from developing negative self, providing material about positive self-development, always evaluating the process, the results of counseling guidance services so that it runs smoothly without encountering many obstacles so as to determine the steps to be taken next. The aim is to make students with introverted personalities become better and more open, both in terms of friendship and in the process of introducing themselves to students.

\section{References}

[1] Walgito. (2003). Pengangtar Psikologi Umum. Yogyakarta: Andi Offset.

[2] Soetjipto, Rafflis Kosasi. (2009). Profesi Keguruan. Jakarta: Rineka Cipta

[3] Yusuf, Nurihsan. (2011). Teori Kepribadian. Bandung: Remaja Rosda Karya.

[4] Prayitno and Erman Amti. (2004). Dasar-dasar Bimbingan Konseling. Jakarta: Gramedia. 
[5] Hambali dan Jaenudin. (2013). Psikologi Kepribadian Lanjutan (Studi atas Teoridan Tokoh Psikologi Kepribadian). Bandung: Pustaka Setia. Hamdi,

[7] Suryabrata, Sumadi. (2011). Psikologi Pendidikan. Jakarta: Raja Grafindo Persada.

[8] Sulistyarini, Jauhar Mohammad. (2014). Dasar-dasar Konseling. Jakarta: Prestasi Pustaka

[9] Yusuf, Nurihsan. (2011). Teori Kepribadian. Bandung: Remaja Rosda Karya

[10] Chaplin, J.P. (2001). Kamus Lengkap Psikologi. Jakarta: Raja Grafindo Persada

[11] Alwisol. (2007). Psikologi Kepribadian. Malang: UPT Universitas Muhammadiyah Malang.

[14] Ghufron and Risnawita. (2014). Teori-teori psikologi. Yogyakarta: Ar-Ruzz Media

[15] Feist Jess \& Gregory. (2013). Teori Kepribadian Buku (1 $1^{\text {st }} 7^{\text {th }}$ Ed). Jakarta: Salemba Humanika. 